\title{
108. Toxic Effect of Human Serum on Cultured Nerve and Muscle Cells of the Chick and Rat
}

\author{
By Kunihiko Obata,*) Akira UEKI,**) and Mitsuo YoshIDA**) \\ (Communicated by Yasuji Katsuki, M. J. A., Sept. 13, 1976)
}

The hypothesis that the sera from patients with neurological diseases contain substances toxic to nerve and muscle cells has been repeatedly examined but not been fully substantiated. Recently the investigations have been extended to cultured cells. Wolfgram and Myers $^{1)}$ reported that in culture of the mouse spinal cord the anterior horn cells were destroyed by the serum from patients with amyotrophic lateral sclerosis (ALS) but not with other 14 degenerative neurological diseases. The selective toxicity of ALS serum, however, was not confirmed by the subsequent investigations. ${ }^{2), 3)}$ Liveson et al.4) found the toxic effects of serum from some patients with myasthenia gravis on mouse muscle cells in culture.

In the present communication we studied the effect of human serum on development of neuromuscular transmission and on growth of large spinal neurons in culture. Some sera were toxic to both types of cultures but the effect was not restricted to the sera from neurological patients.

Neuromuscular transmission. As in the previous paper ${ }^{5)}$ development of neuromuscular transmission was studied by recording spontaneously appearing endplate potentials (epp's) from muscle cells cultured in combination with the spinal cord (Figs. 1A, B). Skeletal muscle cells were obtained by trypsin treatment of pectoral muscles of 10- or 11-day chick embryos or of thigh muscles of newborn rats. The spinal cord was dissected from 6- or 7-day chick embryos and cut into small pieces. First the muscle cells were cultured for 2-5 days in collagen-coated plastic dishes and then the cord fragments were added to the muscle culture. The culture was kept in a humidified $5 \% \mathrm{CO}_{2}$ incubator at $37^{\circ} \mathrm{C}$. Standard culture medium was Eagle's minimal essential medium (MEM) supplemented with 5\% fetal calf serum (Flow Labs.), 5\% chick serum (Flow Labs.) and $2.5 \%$ chick embryo extract. At the time of plating the cord, human serum was added in a final concentration of $10 \%$ to

*) Department of Pharmacology, Gunma University School of Medicine, Showa-mach:, Maebashi-shi 371.

**) Department of Neurology, Jichi Medical School, Minamikawachi-machi, Tochigi-ken 329-04. 

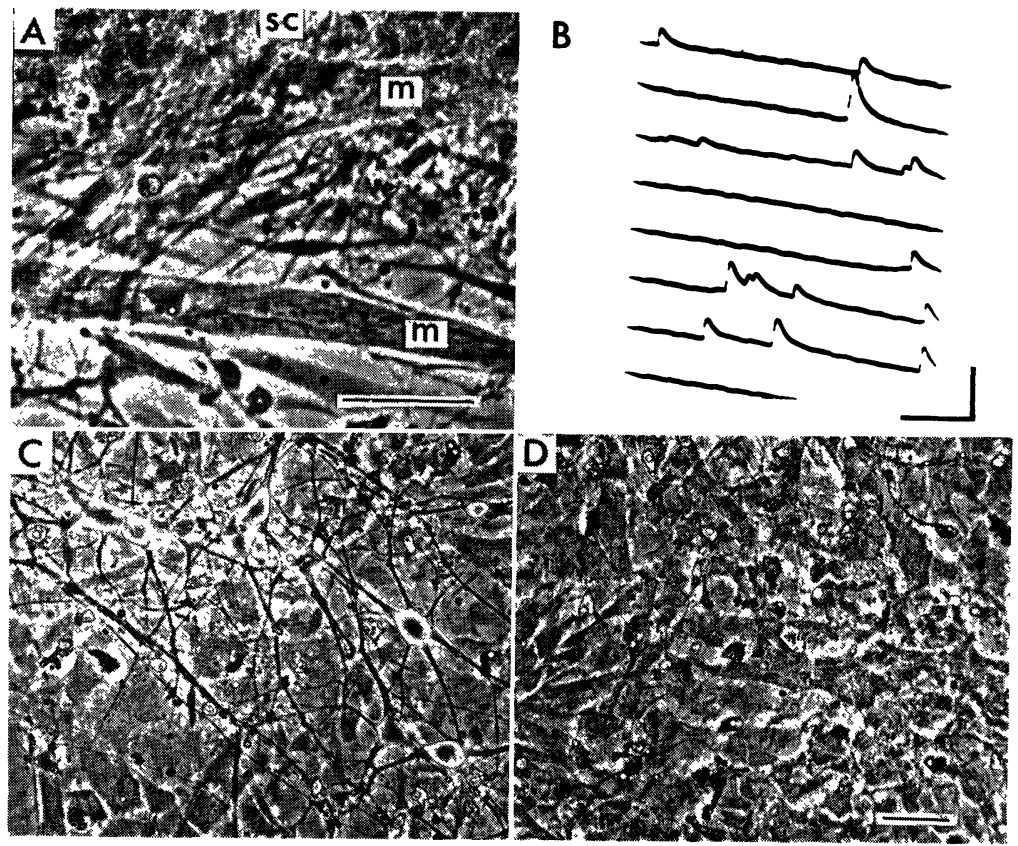

Fig. 1. A: Muscle-nerve culture. Muscle cells (m), 4 days in culture. Explant of spinal cord (sc), 2 days. Bar, $50 \mu \mathrm{m}$. B: Spontaneous endplate potentials (epp's) recorded from a myotube in muscle-nerve culture. Calibration, $20 \mathrm{msec}$ and $10 \mathrm{mV}$. C, D: Culture of dissociated spinal cord. 14 days in culture. C, D, in the presence of $20 \%$ human sera, Nos. 6 and 7 respectively. Bar, $50 \mu \mathrm{m}$.

the chick muscle culture and $25 \%$ to the rat muscle culture. In higher serum concentrations $(20 \%$ for the chick and $35 \%$ for the rat) the muscle cells were detached from the bottom of culture dish, although the growth of nerve processes was less affected.

After 2 days of co-culture intracellular recording was performed on multinucleated muscle cells (myotubes) in the fresh MEM without human serum (Fig. 1A). Percentage of myotubes spontaneously generating epp's (Fig. 1B) is summarized in Table I. In the control cultured without human serum the values were $48 \%$ for the chick myotubes and $43 \%$ for the rat myotubes. About half of the human sera did not affect the incidence of myotubes with epp's. But some sera (Nos. 2, 4, 7, 9 and 10 in Table I) had toxic effect. On the other hand the chick muscle cultured in sera Nos. 5, 8 and 14 showed the higher percentage.

Sera of 3 subjects (Nos. 1, 6 and 9) were taken twice or three times with an interval of 1 or 3 months. The activity was similar for each sample in the same subject. The sera Nos. 9 and 10 were subjected to dialysis. The toxicity remained unchanged after the 
Table I. Effects of human serum on development of neuromuscular transmission and growth of spinal neurons in culture

\begin{tabular}{|c|c|c|c|c|c|}
\hline \multirow[b]{2}{*}{ No. } & \multirow[t]{2}{*}{ Subject } & \multicolumn{2}{|c|}{$\begin{array}{c}\text { Percentage of } \\
\text { myotubes showing } \\
\text { spontaneous end-- } \\
\text { plate potentials }\end{array}$} & \multicolumn{2}{|c|}{$\begin{array}{l}\text { Number of } \\
\text { spinal neurons } \\
\text { over } 25 \mu \mathrm{m} \text { in } \\
\text { diameter }\end{array}$} \\
\hline & & $\begin{array}{l}\text { serv } \\
\text { concent } \\
10 \%{ }^{+}\end{array}$ & $\begin{array}{l}\text { um } \\
\text { ration } \\
25 \% \%^{++}\end{array}$ & $\begin{array}{l}\text { ser } \\
\text { concent } \\
10 \%\end{array}$ & $\begin{array}{l}\text { um } \\
\text { tration } \\
20 \%\end{array}$ \\
\hline 1 & Amyotrophic lateral sclerosis & $48 \%(27) *$ & $35 \%(17) *$ & $23(4) *$ & * $3(3)$ *** \\
\hline 2 & Amyotrophic lateral sclerosis & $26 \quad(46)$ & $29 \quad(7)$ & $11(3)$ & $7(3)$ \\
\hline 3 & Amyotrophic lateral sclerosis & $45 \quad(22)$ & $36 \quad(14)$ & $13(4)$ & $4(4)$ \\
\hline 4 & Spastic spinal paresis and amyotrophy & $0 \quad(6)$ & $48 \quad(11)$ & - & - \\
\hline 5 & Gullain-Barré syndrome & $79 \quad(24)$ & $28 \quad(25)$ & $14(2)$ & $8(1)$ \\
\hline 6 & Bulbar palsy & $48 \quad(27)$ & $35 \quad(17)$ & $17(3)$ & $14(2)$ \\
\hline 7 & Kugelwerg-Welander & $24 \quad(46)$ & $0 \quad(12)$ & $0(4)$ & $0(4)$ \\
\hline 8 & Myasthenia gravis & $84 \quad(25)$ & $9 \quad(22)$ & $3(5)$ & $2(4)$ \\
\hline 9 & Neurologically normal & $21 \quad(38)$ & $52 \quad(33)$ & $2(2)$ & $0(2)$ \\
\hline 10 & Neurologically normal & $0 \quad(2)$ & $40 \quad(10)$ & $\underline{-1}$ & - \\
\hline & Neurologically normal & $41 \quad(12)$ & - & - & - \\
\hline 12 & Neurologically normal & - & $45 \quad(31)$ & $14(2)$ & $13(2)$ \\
\hline & Neurologically normal & $64 \quad(14)$ & - & $1(3)$ & $2(2)$ \\
\hline & Neurologically normal & $87 \quad(23)$ & - & $26(2)$ & $20(2)$ \\
\hline & Neurologically normal & $46 \quad(39)$ & - & $12(4)$ & $14(4)$ \\
\hline & Neurologically normal & $54 \quad(37)$ & $50 \quad(4)$ & $15(4)$ & $12(4)$ \\
\hline
\end{tabular}

+) Tested on chick embryo myotubes after 2 days of co-culture with chick embryo spinal cord.

${ }^{++)}$Tested on rat fetus myotubes after 2 days of co-culture with chick embryo cord.

${ }^{+++)}$Mean numbers of chick embryo neurons per $1 \mathrm{~mm}^{2}$ after 2 weeks of culture.

*) Number of myotubes tested in 2-8 experiments.

**) Number of experiments.

dialysis. The sera Nos. 7 and 9 were incubated at $56^{\circ} \mathrm{C}$ for $30 \mathrm{~min}$. These sera completely lost the toxicity after the heat treatment. The sera Nos. 7 and 9 were tested after storage in a refrigerator for 3 months and no activity remained any more.

Growth of spinal neurons. The spinal cords of 6-day chick embryos were dissociated by trypsin treatment and about $10^{6}$ cells were plated on each collagen-coated plastic dish. ${ }^{6}{ }^{6}$ The standard medium was the same as for the muscle-nerve culture. For the first 2 days cytosine arabinoside $\left(5 \times 10^{-6} \mathrm{M}\right)$ was applied to reduce the proliferation of non-neuronal cells. ${ }^{7}$ Thereafter the medium was changed every 4 days. Human serum was added to a final concentration of $10-20 \%$ on day 10 and the number of neurons over $25 \mu \mathrm{m}$ in diameter was counted on day 14. There was a big difference in 
growth of neurons and their processes, although sheet of nonneuronal cells was almost equally formed (Table I and Figs. 1C, D). In the medium containing some human sera 10 to 25 large neurons with elaborate processes grew in $1 \mathrm{~mm}^{2}$ just as without human serum (Fig. 1C). On the other hand, a few or no neuron was maintained in the presence of other human sera (Nos. 7, 8, 9 and 13 in Table I, Fig. 1D). The effect on neuronal growth seems parallel to that on neuromuscular development but this inference doesn't hold for some cases (Nos. 2, 8 and 13).

In conclusion it was confirmed that several human sera were toxic to culture of nerve and muscle. The toxicity, however, was also found in sera from neurologically normal subjects and not specific to ALS sera. The activity was unaffected by dialysis and lost by heat but further analyses are needed to identify the toxic factor $(\mathrm{s})$.

Acknowledgements. We wish to thank Dr. M. Omine, Department of Medicine Gunma University, for supplying sera Nos. 10-16 in Table I. This work was supported in part by grants from the Ministry of Education (Japan).

\section{References}

1) Wolfgram, F., and Myers, L.: Science, 179, 579-580 (1973).

2) Horwich, M. S., Engel, W. K., and Chauvin, P. B.: Arch. Neurol., 30, 332-333 (1974).

3) Liveson, J., Frey, H., and Bornstein, M. B.: Acta neuropath. (Berl.), 32, 127-131 (1975).

4) Liveson, J. A., Godman, G., Kornfeld, P., and Bornstein, M. B.: Exp. Neurol., 50, 620-627 (1976).

5) Obata, K.: Brain Res., in press.

6) Obata, K., and Akaike, T.: J. Physiol. Soc. Japan, 37, 230-231 (1975) (in Japanese).

7) Fischbach, G. D.: Develop. Biol., 28, 407-429 (1972). 